Определены главные противоречия между действием объективных закономерностей формирования политической карты мира в XXI в. и принципами международных отношений. Они состоят в отставании сформированных принципов международных отношений от изменений на политической карте мира.

Ключевые слова: политическая карта мира, закономерности формирования политической карты мира, принципы международных отношений.

P. Masliak, Doctor of Science in Geography, Professor

Taras Shevchenko National University of Kyiv, Kyiv, Ukraine

\title{
POLITICAL GEOGRAPHY OF XXI CENTURY
}

The main regularities of the formation of the political map of the world and its individual regions in XXI century.

Socio-geographical patterns in the field of political geography are determined by two objective factors. The first is that over time, complexity of any territory increases. This is due to the fact that with the development of civilization and population growth, the territory of any taxonomic rank is constantly becoming more complex. More and more people and objects appear on it. Thus, smaller areas of size receive objective advantages over large ones.

The second factor is determined by fact that on the political map of the world the number of countries absolutely does not coincide with the number of nations. The latter at least 50 times more. However, also absolutely objectively, no nation can fully realize its potential without the formation of a national state.

Proposed psychological-mental approach to the assessment of spatial-territorial factors in political geography.

The main contradictions between the action of objective laws of forming map of the world in the XXI century and the principles of international relations.

Thus, on the basic of objective statement that can be considered as axioms, we obtain the main interrelated patterns of forming a political map of the world in the XXI century. These include: the pattern of imminent collapse of empires; pattern of gradual increase in the number of countries on the political map of the world; the pattern of creation of national countries; regularity of the geopolitical pendulum of history.

In XXI century the importance of spatial and territorial factors in the development of the political map of the world. Moreover, their implementation will take place against the background of psychological and mental local impulses. The development of individual countries will increasingly depend on the balance of their territories in a changing geopolitical space.

Keywords: a political map of the world, regularities of the formation of the political map of the world, principles of international relations.

http://doi.org/10.17721/1728-2721.2018.72.3

УДК 551.584.5

О. Шевченко, канд. геогр. наук, доц., С. Сніжко, д-р геогр. наук, проф.

Київський національний університет імені Тараса Шевченка, Київ, Україна

\section{ВІТРОВИЙ РЕЖИМ ВЕЛИКОГО МІСТА}

Розглянуто особливості вітрового режиму урбанізованого середовища. Висвітлено основні чинники, що визначають формування поля вітру великого міста. Розкрито механізм та описано необхідні умови для утворення сільського бризу. Охарактеризовано основні трансформації повітряного потоку в міському каньйоні, які можуть формуватися залежно від напрямку вітру, а також від характеристик та напрямку каньйону. Наведено особливості обтікання повітряним потоком окремих будівель та охарактеризовано зону зміщення повітряного потоку, зону вітрової тіні та зону вирівнювання потоку, що формуються при цьому.

Ключові слова: вітер, вітровий режим великого міста, урбанізоване середовище, послаблення вітру в місті, сільський бриз, аерація великого міста, вітрова тінь, трансформації вітру в міському каньйоні.

Постановка проблеми. Упродовж останніх десятиліть процес урбанізації відбувається швидкими темпами. Разом зі зростанням розмірів міст зазнають значних змін і всі компоненти природного середовища, як усередині самого міста, так і на прилеглих до нього територіях. Зміни, що спричинені урбанізацією в локальній структурі атмосферного граничного шару, здійснюють значний вплив на перебіг атмосферних процесів та призводять до зміни значень основних метеорологічних елементів. Поле швидкості вітру над містом майже завжди має складну структуру. Навіть у тому випадку, коли погодна ситуація є максимально простою (безхмарне небо та слабкий вітер або штиль за антициклональної ситуації) відмінності у властивостях підстильної поверхні, особливості рельєфу й параметри забудови спричинюють невпорядковані повітряні рухи [2]. Часто в літературі вітровий режим приземного шару повітря (т. зв. шару життєдіяльності людини - від рівня землі до висоти 2 м) урбанізованого середовища називають аераційним режимом [1]. Аерація житлової території важливий чинник довкілля, адже саме ним визначаються умови формування рівня забруднення атмосфрерного повітря та біоклімату території. Аераційний режим міста формується як результат кліматичних умов території (вітровий режим) та впливу різноманітних перешкод (забудови), схеми вулично-дорожньої мережі, зелених насаджень, водойм та інших об'єктів, що можуть впливати на рух повітря у приземному шарі.
Створення належного аераційного режиму урбанізованих територій визначається прийомами архітектурного планування і забудови, принципами озеленення та благоустрою, типами й конструкціями будівель [1]. Залежно від потреби - в окремих точках території можуть створюватися умови для вітрового затінення, або навпаки - сприятливі умови для провітрювання. Саме для того, щоб мати можливість якнайточніше виконати корегування аераційного режиму території, створити максимально комфортний біоклімат у межах районів міста, які проектуються й будуються, забезпечити достатній рівень провітрювання районів, що розташовані поблизу джерел викидів забруднювальних речовин (а, відповідно, і задовільну якість повітря в них) постійно проводяться дослідження вітрового режиму великих міст і чинників, що на нього впливають.

Аналіз попередніх публікацій та досліджень. Дослідження характеристик вітру великого міста розпочалися доволі давно - понад 100 років тому вже була встановлена основна та найзагальніша відмінність вітрового режиму урбанізованих територій - зменшення швидкості вітру порівняно із приміськими незабудованими територіями. Ще в 1909 р. у результаті спостережень у Берліні з використанням анемометра В. Кремсер уперше встановив цю закономірність. Подальші дослідження, здійсненні в різних містах світу, також підтвердили зниження середньої швидкості вітру в урбанізованому середовищі [10]. Значний внесок у розвиток дос- 
ліджень трансформацій вітрового режиму в місті зробили H. Lansberg [10], T. R. Oke, G. Mills, A. Christen, J. A. Voogt [13], W. Kuttler [7], E. Erell, D. Pearlmutter, T. Williamson [9] тощо.

На сьогодні для вивчення поля вітру в урбанізованому середовищі широко застосовується моделювання. Фізичне - реалізовується шляхом продування макету забудови в аеродинамічній трубі, математичне - за допомогою різноманітних програмних продуктів (напр., "Airflow", "Envi-Met"). Причому, другий підхід в останні роки все частіше застосовується навіть на теренах України. Проте, як показав аналіз публікацій, присвячених даній тематиці - доволі часто фахівці можуть успішно здійснити моделювання повітряних потоків у межах складного урбанізованого середовища, але далеко не завжди можуть вірно інтерпретувати отримані результати. Саме тому метою даної статті є вивчення й аналіз вітрового режиму великого міста, а також узагальнення основних закономірностей трансформацій повітряного потоку в його межах для подальшого використання цієї інформації в наукових дослідженнях та для успішного корегування аераційного режиму урбанізованих територій.

Виклад основного матеріалу. У середньому за рік зниження швидкості вітру в містах порівняно з їх околицями становить близько 30 \%. Майже у всіх дослідженнях спостерігається, що в місті більше безвітряних днів та днів зі слабкими вітрами, що не перевищують $2 \mathrm{~m} / \mathrm{c}$, ніж у сільській місцевості. За даними [8] кількість штилів у містах зростає на $20 \%$. Максимальна швидкість вітру в більшості випадків у середньому на 10-30\% нижча, порівняно із незабудованою територією. На територіях із забудовою високою щільністю і всередині груп будівель, що утворюють замкнені й напівзамкнені внутрішньодворові території, швидкість вітру знижується на $70 \%$ і більше [4].

Дослідження вітрового режиму, проведені у великих містах України, також свідчать про послаблення швидкості вітру: наприклад у Києві швидкість вітру в усі пори року протягом доби на більшості території в 0,60,7 рази менша, ніж за його межами (Бориспіль), а майже в усіх районах міста у 1,5-2,5 рази більша, ніж у центрі; у Харкові відношення швидкості вітру в центрі міста до його значень на позаміській території стано- вить 0,7 ; у Полтаві - у центрі міста і промисловій зоні швидкість вітру в 1,5-2,0 рази менша, ніж на околиці; у центрі Львова, розташованого в улоговині, швидкість вітру майже завжди найменша, порівняно з передмістям та іншими районами міста; центральна частина Луцька, як і інших міст, характеризується меншою швидкістю вітру порівняно з околицями; відношення швидкості вітру в Дніпрі до його значення за містом змінюється переважно у межах 0,75-0,85 [2]. Хоча при цьому на підвищених і відкритих місцях в окремий час доби швидкість вітру може наближатися до показників у заміській зоні (напр., таке спостерігається на Багриновій горі в Києві), або навіть бути дещо вищою (у Дніпрі на підвищених $\mathrm{i}$ добре провітрюваних територіях в окремі години доби швидкість у 1,2-1,3 рази вища, ніж за містом) [2].

Послаблення швидкості вітру в урбанізованому середовищі відбувається в першу чергу за рахунок вищої шорсткості міської поверхні, порівняно із природними ландшафтами, особливостей рельєфу, або за рахунок "бар'єрного ефректу" - місто із простим рельєфом відіграє роль пасивної перешкоди на шляху повітряного потоку, що спричинює тенденцію до бокового обтікання міста повітряним потоком, а також за рахунок цього до зростання вертикальної компоненти швидкості вітру. Швидкість висхідного потоку в таких випадках у денний час може становити приблизно 0,3-0,4 м/с [11], а швидкість горизонтальної складової, відповідно, зменшується.

Крім того, у багатьох містах на швидкість вітру впливає рослинність. Дослідження, проведені у Відні, показали, що зелені крони дерев зменшують швидкість вітру на 20-30\%. Аналогічний ефект заффіксований у Нешвілі (США) - вимірювання швидкості вітру показали, що в літній сезон на численних озеленених ділянках швидкість вітру була на 20-30\% меншою, ніж на неозеленених. Після опадання листя вітер у середньому посилювався на 25-40 \% [10].

У межах урбанізованої території знижується не лише середня швидкість вітру, порівняно із сільською місцевістю, а також відрізняється вертикальний профіль вітру від розподілу швидкостей вітру над рівною територією [4]. Ці відмінності не є однаковими на різних ділянках і залежать від щільності забудови, ії висоти, контрастності та інших морфометричних показників та характеру благоустрою (рис. 1).

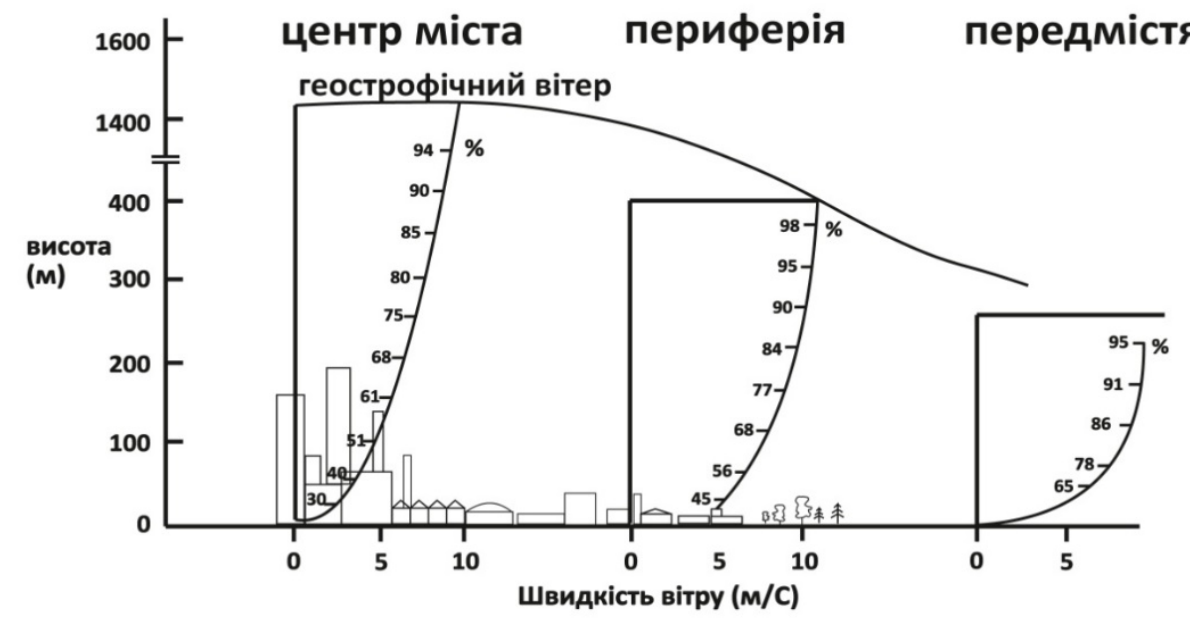

Рис. 1. Узагальнена схема вертикального профілю швидкості вітру над центром міста, його периферією та у приміській зоні [4] 
Крім того, варто зазначити, що навіть загальні особливості відмінностей вітрового режиму урбанізованого середовища будуть відрізнятися для міст із різними типами забудови. За висотою забудови виділяють такі типи міст: "місто-чаша", що характеризується збільшенням висотності будівель від центральної частини міста до периферії, "місто-пагорб" - висотні об'єкти розташовані в центральній частині міста, а до периферії відбувається поступове зниження висотності будівель і "місто-рівнина", в якому приблизно однакова висота забудови спостерігається по всій його території (або по всій території міста спостерігаються чергування будівель різної висоти) [5].

М. С. Мягков [4] зазначає, що зміна вітрового режиму в межах міської забудови, з одного боку, є очевидною та передбачуваною, а з іншого - підпорядковується доволі складним законам гідротермодинаміки, тому $є$ не такою простою. Міська забудова, маючи коефіцієнт шорсткості вищий, ніж більшість природних ландшафтів, знижує швидкість повітряного потоку біля земної поверхні, а за рахунок підвищеної тепловіддачі в атмосферу місто створює мезомасштабну термічну конвекцію, яка може посилювати швидкість вітру на фоні штильових умов. Острів тепла (ОТ), що є причиною підвищеної тепловіддачі в місті, спричинює додаткові горизонтальні градієнти тиску та пов'язані з ними локальні циркуляції, які можуть виникати за слабких вітрів або штилю. Біля поверхні землі повітряні потоки спрямовані від окраїн до центру, де найвища інтенсивність ОТ, а у верхньому шарі спостерігається відтік повітря до околиць міста. Наявність конвергенції приповерхневого повітряного потоку над містом $€$ логічною, адже внаслідок існування острова тепла формується нестійка стратифрікація температури, що викликає підйом повітряних мас. Вищеописана циркуляція називається сільським бризом (рис. 2).

Нічна конвергенція повітряного потоку над містом $€$ причиною того, що вночі вітер у місті послаблюється не настільки сильно, як удень, і часом може бути навіть сильнішим, ніж у сільській місцевості. Найчастіше це спостерігається за тихої спокійної погоди, коли в сільській місцевості фріксується потужна температурна інверсія, а в місті приповерхневий шар повітря стратифікований нестійко.

Тепле повітря

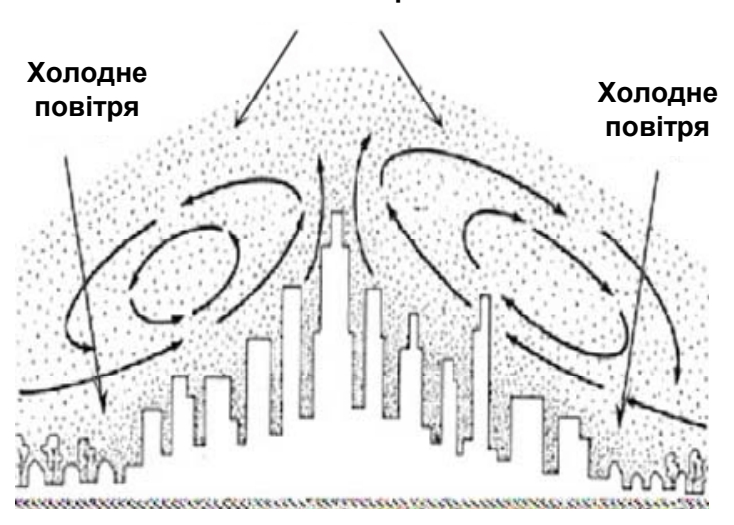

Рис. 2. Схема формування сільського бризу [6]

Варто зазначити, що спрямований вночі всередину міста рух повітря не є постійним. У великих містах ізотерми ОТ (навіть якщо він на території даного міста єдиний) розташовані не еквідистантно. Зазвичай ізотерми концентруються біля краю щільно забудованої зони. У метеорології така ситуація аналогічна до проходження холодного фронту, коли на незначній відстані відбувається різка зміна температури. Ця особливість островів тепла може призводити до різких пульсацій холоднішого повітря, що надходить у місто вночі, і супроводжуватися сильними поривами вітру. Існування таких мініатюрних холодних фронтів було доведено А. Шмауссом ще в 1925 р. [10].

Проте E. Erell та D. Pearlmutter [9] зазначають, що хоча мезомасштабні метеорологічні моделі урбанізованих територій передбачають існування у містах термічних циркуляцій типу сільського бризу, проте емпіричні дані стосовно цього явища не завжди є однозначними. Це може бути спричинено тим, що термічні циркуляції можуть формуватися лише в особливих умов: поперше, лише в нічний час та за високої інтенсивності міського ОТ і за дуже слабкого вітру чи штилю. Крім того, коли під впливом міського ОТ формується сільський бриз, адвекція повітря із передмість діє як саморегулюючий механізм, що знижує температурну різницю між містом і приміськими районами: порівняно холодні- ше повітря надходить у місто в нижньому шарі (біля земної поверхні), у той час як тепле повітря піднімається вгору і виноситься за межі міста, таким чином відбувається руйнування температурних відмінностей між містом та прилеглими територіями.

Особливості вітрового режиму в межах різних типів забудови. Велике місто, як правило, є мезомасштабною перешкодою на шляху вітру (за рахунок чого виникає тенденція до бокового обтікання міста повітряним потоком - про що згадувалося вище), проте ця "перешкода" поділена на дрібніші - субмезомасштабні фрагменти (мікрорайони, комплекси будівель), що відрізняються за своїми аеродинамічними параметрами, і у свою чергу поділяються на мікромасштабні об'єкти (окремі будівлі, частини вулиць тощо).

Повітряні потоки всередині міського шару тертя значною мірою залежать від особливостей місцевості та розміщення перешкод. Суттєві відмінності спостерігаються між порушенням повітряного потоку перешкодами, що спричинюють його поділ (перешкоди з чіткими гранями, такі як, напр., високі будівлі) та такими, що дають змогу потоку плавно обтікати їхні поверхні (перешкоди округлих форм, такі, як невисокі пагорби чи неглибокі долини). Міські конструкції звісно ж є перешкодами першого типу - їх інколи називають необтічни- 
ми тілами (bluff body - англ.) [9] (їхні кутові краї стають причиною утворень інтенсивних вихорів).

Для кращого розуміння особливостей зміни вітрового потоку в міському середовищі, краще розглянути спочатку особливості обтікання повітряним потоком спрощеного двовимірного об'єкта. Коли повітряний потік, паралельний землі, наштовхується на будівлю, що належить до необтічних перешкод та розташована далеко від інших, відбувається суттєва його трансформація і в ньому можна виділити три зони, що суттєво відрізняються за своїми характеристиками (рис. 3). Перша 3 цих зон (зона зміщення) починається на певній відстані перед будівлею $з$ навітряного боку, підіймається дещо вище ії даху і тонкою смугою тягнеться з підвітряного боку над двома іншими зонами трансформації потоку аж до місця, де відбувається його вирівнювання. Безпосередньо перед будівлею, на деякій висоті над нею та за нею розташовується зона вітрової тіні, яка за рахунок фрормування вихорів характеризується значно нижчою швидкістю вітру, і в різних публікаціях ще називається зоною аеродинамічної тіні, зоною відносного штилю чи зоною завихрення. Частина зони вітрової тіні перед будівлею $€$ помітно меншою, ніж підвітряна їі частина, і часто виділяється окремо й називається зоною підпору. Розміри зони вітрової тіні визначаються висотою, довжиною та шириною будівлі й розраховуються за спеціальними формулами. Наближено зона вітрової тіні може бути прийнята як п'ять висот будівлі [3]. Третя зона у структурі повітряного потоку - це зона вирівнювання (відновлення) потоку, вона розташована лише з підвітряного боку будівлі.

Крім того, залежно від розташування будівлі шодо вітрового потоку можливі різні варіанти завихрення повітря в зоні вітрової тіні (рис. 4), що у свою чергу визначає також ії розміри та силу всмоктуючого ефректу (зону за будівлею з негативним тиском). Якщо будівля розташована під кутом $45^{\circ}$ до повітряного потоку, то вздовж ії̈ навітряних граней формуються високі швидкості вітру (на відміну від випадку, коли будівля розташована до вітру лицьовим боком і перед нею формується завихрення), вітрова тінь за нею $є$ значно ширшою, а всмоктуючий ефект - сильнішим.

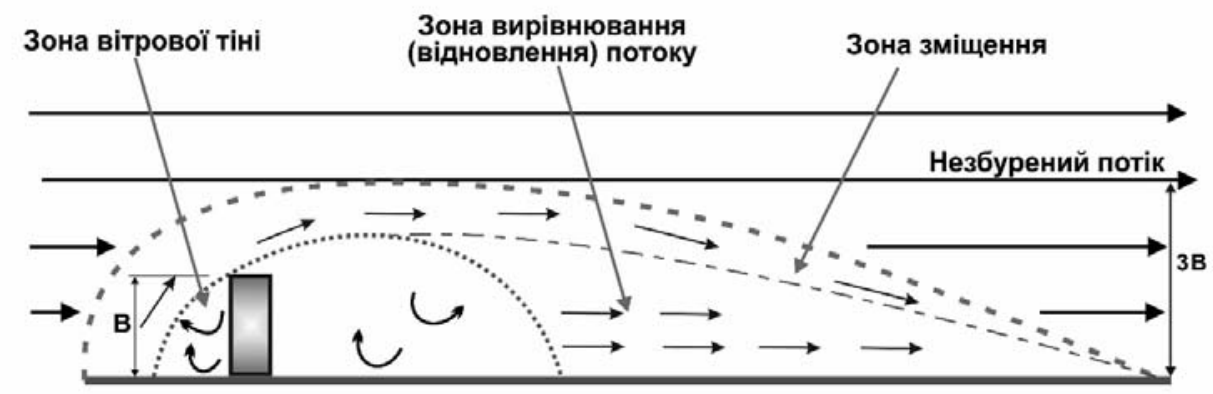

Рис. 3. Схематичне зображення структури повітряного потоку, що наштовхнувся на будівлю, яка розташована на значній відстані від інших [9]

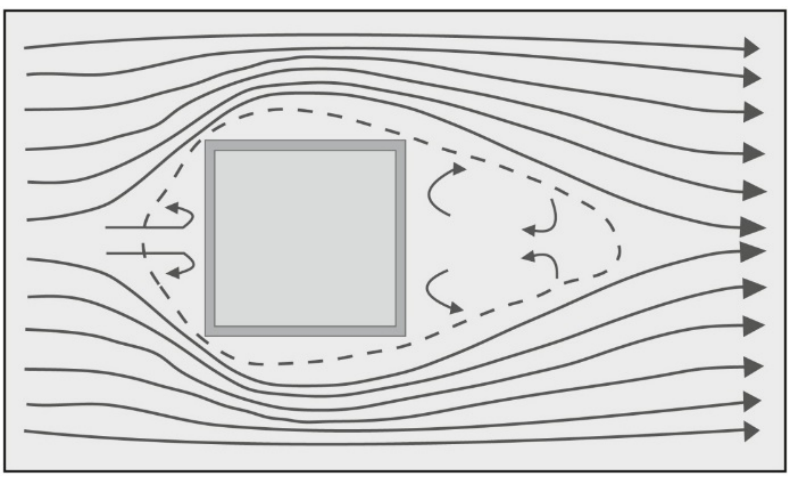

а) обтікання будівлі,

що розташована до вітрового потоку лицьовим боком

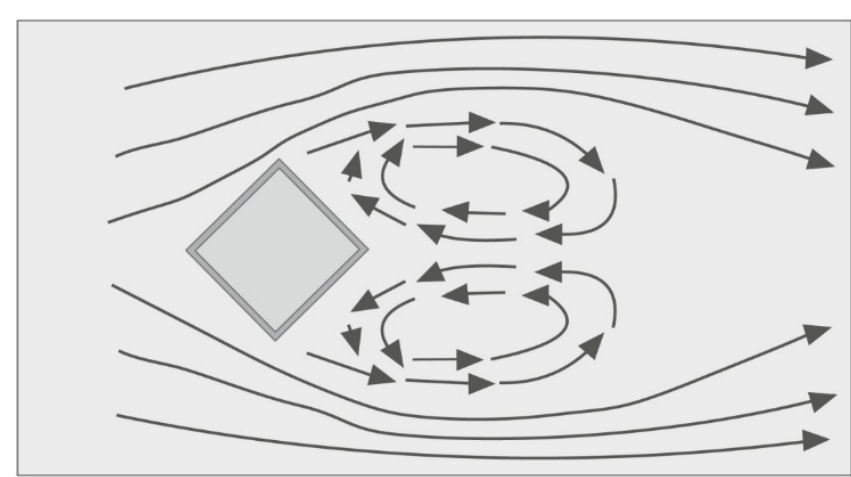

б) що розташована кутовим боком до вітру

Рис. 4. Схематичне зображення структури повітряного потоку, що обтікає одиноко розташовану будівлю (вигляд зверху) [12]

Однак у реальних умовах міські будівлі $є$ тривимірними об'єктами і повітряний потік, обтікаючи їх, не просто перевалюється через них зверху, але й обтікає їх із боків (наштовхнувшись на нерухому перешкоду, повітряний потік розділяється і його частини рухаються доверху, донизу та в різні боки, огинаючи будівлю з боків). Повітря, упираючись у стіну будинку, створює відносно високий тиск дещо вище середньої частини стіни, де вітровий потік зупиняється і тиск зменшується назовні від цієї точки гальмування. Оскільки повітря рухається від високого тиску до низького, то крім руху повітря у вже зазначених напрямках також виникає рух повітря вниз по стіні, і потім формується так званий зворотній потік (reverce flow - англ.) (рис. 5). 


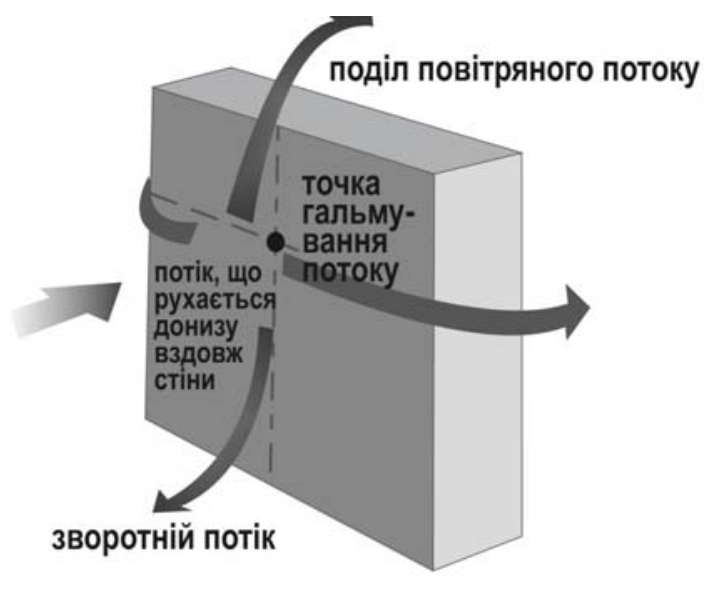

Рис. 5. Приклад повітряних потоків навколо висотної будівлі [9]

У міському середовищі на характеристики вітру впливає не одна перешкода з певними параметрами (як це розглянуто вище), а цілий комплекс чинників, що можуть призводити, як до зміни напрямку вітру в міському середовищі, так і до локального посилення чи послаблення вітру. До них належать форма та розміри будівель, характеристики вулиць та їх чергування з відкритими територіями, особливості топографії тощо.

Найуживанішою моделлю забудови, що застосовується для вивчення зміни характеристик вітру в урбанізованому середовищі, є міський каньйон. Для трансформації вітрового потоку в межах міського каньйону характерні такі закономірності:

І. Якщо напрямок вітру (первинний потік) є паралельним або майже паралельним (відхилення менше $30^{\circ}$ ) до напрямку міського каньйону, то повітря, опускаючись в каньйон і формуючи вторинний потік, буде збільшувати швидкість вітру в каньйоні. Це відбувається згідно 3 ефректом Вентурі: при звуженні трубки швидкість газу зростає пропорційно зменшенню площі її поперечного перерізу, статичний тиск при цьому відповідним чином зменшується - щось подібне відбувається в умовах щільно забудованого міського середовища. Для позначення трансформацій руху повітряного потоку в межах даного типу забудови доволі часто використовують термін - вітри міських каньйонів.

II. Якщо напрямок вітру є перпендикулярним до напрямку міського каньйону (первинний потік), то в каньйоні формуватиметься вихровий потік (вторинний) i, відповідно, буде спостерігатися послаблення швидкості вітру. Вторинний потік залежно від характеристик каньйону може набувати різних форм і складатися з одного або кількох вихорів.

Дослідження свідчать, що у простому міському каньйоні, орієнтованому таким чином, що його вісь перпендикулярна до напрямку вітру, можуть бути виділено три різних типи вітрового режиму, що залежать від характеристик каньйону (співвідношення висоти до ширини каньйону (В/Ш) та довжини до ширини (Д/Ш)). Перехід від одного режиму до іншого відбувається за певних граничних значень співвідношень В/Ш та Д/Ш.

1. Ізольовані збурення потоку. Коли відстань між будівлями відносно велика (співвідношення В/Ш між ними менше, ніж 0,3-0,5), то повітряний потік обтікає кожну будівлю як окрему перешкоду і циркуляції біля кожної з будівель не взаємопов'язані [9]. У такому випадку фрормуються такі порушення повітряного потоку (рис. 6, а). У зоні зміщення, розташованій на підході до будинку, фрормується підпираючий вихор. Максимальний тиск спостерігається дещо вище середини стіни, де відбувається застій вітру і тиск знижується від цієї точки. Якщо будинок із гострими кутами, то повітряний потік розділяється, обтікає перешкоду зверху та з боків, формуючи зону втягування. У двовимірному перерізі безперервного міського каньйону вважається, що це зона завихрення зі зниженим тиском, яка спостерігається над дахом та з підвітряного боку стіни будівлі, де повітря втягується у вир підвітряної циркуляції зворотної до основного потоку повітря. Із підвітряного боку перешкоди в зоні низького тиску поділ потоку створює сильнішу турбулентність, ніж вона була у вільному потоці. У результаті цього поділу, сила вітру біля поверхні землі слабшає і швидкість зменшується.

2. Iнтерфреренція повітряних потоків. За меншої відстані між будинками в межах міського каньйону та, відповідно, більшому значенні співвідношення висоти забудови до відстані між нею $(0,5<\mathrm{B} / Ш<0,65)$, підпираючий вихор із навітряного боку та підвітряні циркуляції діють одночасно, збільшуючи турбулентність під впливом первинних потоків зони вирівнювання (рис. 6, б). Незважаючи на більше збурення повітряного потоку, середня швидкість вітру $є$ нижчою в такій ситуації, ніж у випадку більшої відстані між будівлями (що розглянуто вище).

3. Режим ковзаючого потоку. Коли будівлі близько розташовані (таким чином, що відношення В/Ш більше, ніж 0,65), каньйон може вважатися захищеним від прямого впливу вітру, перпендикулярного до осі каньйону. У такому випадку стабільний циркуляційний вихор, який спостерігається в межах каньйону, формується завдяки передачі імпульсу, проте більша частина повітряного потоку не входить ууу каньйон. Основний потік "ковзає" над будинками і вітер в межах забудови є слабким (рис. 6, в) [9]. 


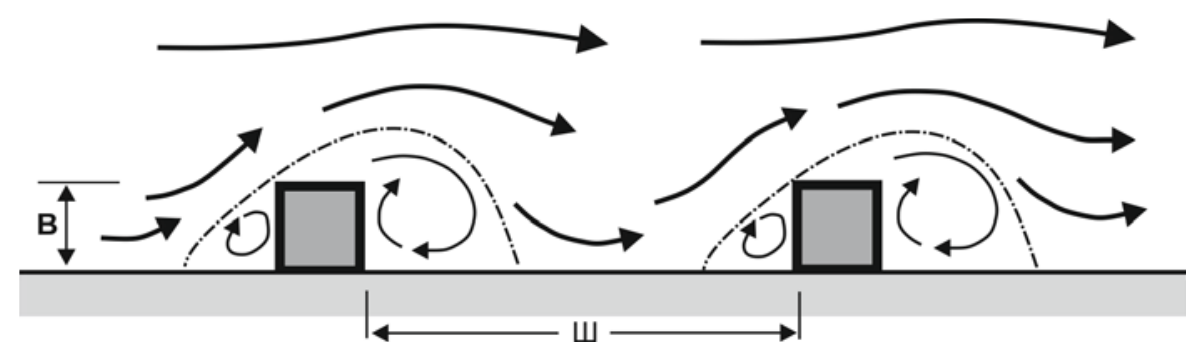

а) ізольовані збурення повітряного потоку в міському каньйоні

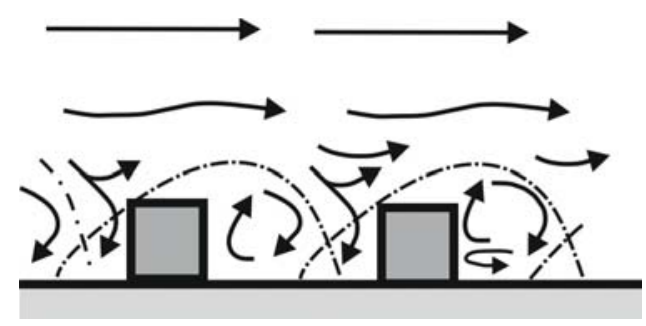

б) інтерференція повітряних потоків у міському каньйоні

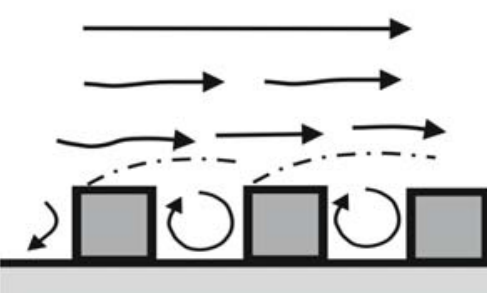

В) схема ковзаючого потоку, який перпендикулярний міському каньйону

Рис. 6. Режими руху повітряного потоку в міському каньйоні, якщо напрямок вітру є перпендикулярним до його напрямку [12]

Залежно від висоти Сонця та розташування осі каньйону відносно сторін горизонту, формуються відмінності в освітленості різних частин вулиці та, відповідно, більш нагрітою може бути одна з його сторін або дно каньйону. Це впливає на формування структури вихрового потоку в межах каньйону: теплий потік утворюється над поверхнею освітлених стін і піднімається вгору, а холодний потік утворюється над затіненими частинами вулиць і дворів та спускається вниз.

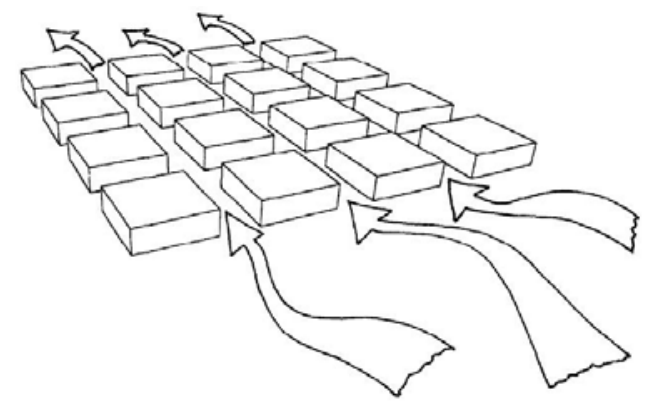

a)

Рис. 7. Можливі схеми забудови міських районів та розподіл вітрових потоків у їх межах [14]

У випадку, якщо в межах забудови не всі будівлі однакової висоти, рух повітря відбуватиметься за такою схемою: перед високою будівлею повітряний потік буде розділятися і одна частина підійматиметься вгору (вище рівня дахів), інша частина - буде опускатися донизу формуючи дуже сильний вихор і створюючи сильний
Крім того, варто зазначити, що якщо ми розглядаємо квартальну забудову міста, то хоча вона й складається 3 коротких каньйонів (Д/В = 3), проте в її межах усе одно відбувається зростання швидкості вітру, якщо він спрямований уздовж каньйону (рис. 7, a), тому, якщо це $є$ небажаним явищем, при забудові слід проектувати вулиці таким чином, щоб вони якомога частіше змінювали свій напрямок (рис. 7, б).

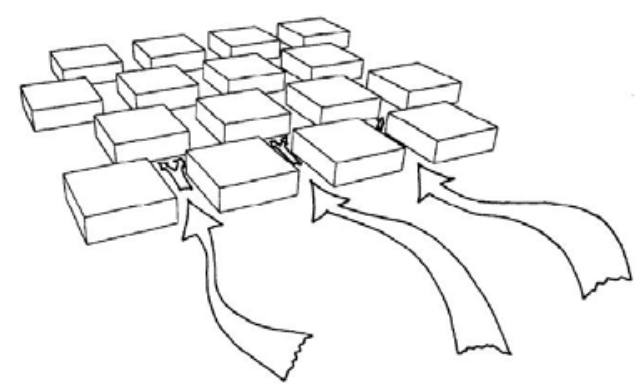

б)

тиск на будівлю. Підвищені швидкості руху повітряного потоку спостерігаються з боків високої будівлі.

Якщо в межах забудованої території повітряний потік, рухаючись, потрапляє в ділянку, де відбувається його звуження, спостерігається ефект Вентурі (як і в межах міського каньйону) - зростає швидкість руху та зменшується тиск (рис. 8). 


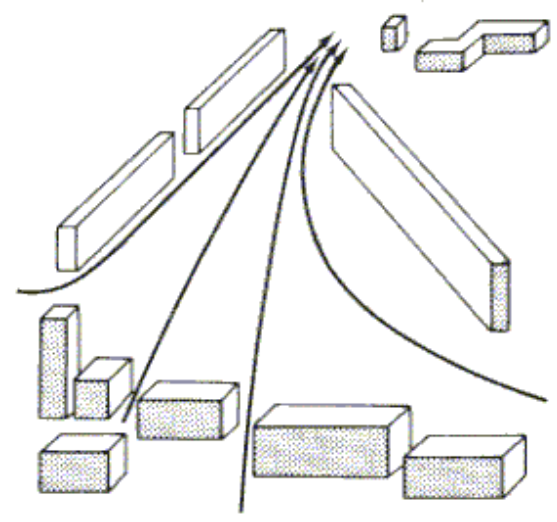

Рис. 8. Посилення швидкості руху в межах міської забудови згідно з ефектом Вентурі

В умовах реальної міської забудови поле вітру має дуже складну структуру, адже одночасно відбуваються всі вищеописані види трансформацій повітряного потоку. Крім того, напрямок і швидкість вітру може суттєво відрізнятися в межах міського піддахового шару та вище розташованих шарів міського граничного шару, що залежить від співвідношення висоти будівель до відстані між ними та їхнього взаємного розташування.

Висновки. Основною та найзагальнішою відмінністю вітрового режиму урбанізованих територій є зменшення швидкості вітру у містах (приблизно на $30 \%$ ), порівняно з їх околицями. Однією із причин формування цієї відмінності $є$ обтікання міста повітряним потоком як простої перешкоди - у такому випадку зростає вертикальна компонента швидкості вітру (що за сприятливих умов може сягати до 0,4 м/с) i, відповідно, знижується горизонтальна. У межах урбанізованої території знижується не лише середня швидкість вітру, порівняно із сільською місцевістю, а також помітно відрізняється вертикальний профріль вітру. Існування острова тепла приводить до формування в місті мезомасштабної термічної циркуляції - сільського бризу, що найкраще виявляється за штильових умов або слабких вітрів. Трансформація повітряного потоку в міському каньйоні залежить від його напрямку та напрямку вітру - якщо вони збігаються, то повітря, потрапляючи в каньйон, формуватиме вторинний потік із вищою швидкістю (відповідно до закону Вентурі). Якщо ж напрямок вітру є перпендикулярним до напрямку каньйону - то в каньйоні буде відбуватися фрормування вихрових потоків і, відповідно, спостерігатиметься ослаблення швидкості вітру. Залежно від характеристик каньйону (співвідношення його висоти до ширини та довжини до ширини), у ньому можуть бути виділені три різних типи вітрового режиму: ізольовані збурення потоку, інтерференція повітряних потоків та режим ковзаючого потоку.

Отже, поле вітру в умовах міської забудови має дуже складну структуру, адже вітровий режим великого міста формується як сума вітрів синоптичного процесу, термічних циркуляцій та механічних порушень повітряного потоку під впливом міських перешкод.

Вище описані закономірності вітрового режиму урбанізованої території мають ураховуватись при архітектурному плануванні та забудові міст з метою створення належного аераційного режиму, зниження рівня забруднення атмосферного повітря, створення комфортного біоклімату тощо.

Список використаних джерел:

1. Гордюк І.В. Комп'ютерне моделювання повітряних потоків у міській забудові / І. Гордюк, Ю. Дорошенко // Новітні комп'ютерні технології. - 2013. - Вип. XI. - С.166-168.
2. Ліпінський В. М. Клімат України / В. М. Ліпінський, В. А. Дячук, В.М. Бабіченко ; за ред. В. М. Ліпінського. - К., 2003.

3. Проектирование, строительство и эксплуатация высотных зданий с учетом аэродинамических аспектов / М. К. Михайлова, В. С. Далинчук, А. В. Бушманова, Л.В.Доброгорская // Строительство уникальных зданий и сооружений. - 2016. - №10 (49). - С. 59-74.

4. Мягков М. С. Город, архитектура, человек и климат / М. С. Мягков, Ю.Д.Губернский, Л.И. Конова и др. ; под ред. М. С. Мягкова. - М., 2007.

5. Особенности ветрового режима типовых форм городской настройки [Електронний ресурс\}. - Режим доступа: http://www.marhi.ru/ AMIT/2014/1kvart14/myagkov/abstract.php.

6. Background on Urban Growth and Urban Heat Islands [Електронний ресурс]. - Режим доступа: http://rsd.gsfc.nasa.gov/912/urban/background.htm.

7. Barlag A.-B. The significance of country breezes for urban planning / A.-B. Barlag, W. Kuttler // Energy and buildings. - 1990/91. - 15-16. C. $291-297$.

8. Climate booklet for urban development: references for zoning and Planning. Baden-Württemberg Innen Ministerium. - Stuttgart, 2004

9. Erell E. Urban Microclimate : Designing the Spaces Between Buildings / E. Erell, D. Pearlmutter, T. Williamson. - London; Washington, DC, 2012. - $452 \mathrm{p}$

10. Landsberg H. E. The Urban Climate / H. E. Landsberg. - N. Y., 1981.

11. Landsberg H. E. The Urban Climate // International Geophysics Series. - 1981. - Vol. 28. - P. 769-779.

12. Oke T. R. Boundary Layer Climates -2 nd ed. - M. ; L.; N.Y., 1987.

13. Oke T.R. Urban Climates / Oke T.R., Mills G., Christen A. and other. - C., 2017.

14. Santamouris $M$. Thermal and air flow characteristics in a deep pedestrian canyon under hot weather conditions / M. Santamouris, N. Papanikolaou, // Koronakis and other // Atmospheric Environment. 1999. - Vol. 33. - P. 4503-4521.

References:

1. Gordyuk I. V., Doroshenko YU. O. Komp'yuterne modelyuvannya povitryanih potokiv u miskiy zabudovi // Novitni komp'yuterni tehnologiï. 2013. - Vyp. XI. - S. 166-168.

2. Lipinskiy V.M., Dyachuk V.A., Babichenko V.M. Klimat Ukraïni / za red. V. M. Lipinskogo. - K., 2003.

3. Mihaylova M.K., Dalinchuk V.S., Bushmanova A.V., Dobrogorskaya L.V. Proektirovanie, stroitelstvo i ekspluatatsiya vyisotnyih zdaniy s uchetom aerodinamicheskih aspektov // Stroitelstvo unikalnyih zdaniy i soorujeniy. - 2016. - № 10 (49). - S. 59-74.

4. Myagkov M. S., Gubernskiy YU. D., Konova L. I., Litskevich V. K. Gorod, arhitektura, chelovek i klimat / Pod red. M.S. Myagkova. - M., 2007.

5. Osobennosti vetrovogo rejima tipovyih form gorodskoy zastroyki [Elektronniy resurs]. - Rejim dostupu: http://www.marhi.ru/AMIT/2014/ $1 \mathrm{kvart14/myagkov/abstract.php.}$

6. Background on Urban Growth and Urban Heat Islands [Elektronniy resurs]. - Rejim dostupu: http://rsd.gsfc.nasa.gov/912/urban/background.htm.

7. Barlag A.-B., Kuttler W. The significance of country breezes for urban planning // Energy and buildings. - 1990/91; 15-16. - S. 291-297.

8. Climate booklet for urban development: references for zoning and Planning. Baden-Württemberg Innen Ministerium. - Stuttgart, 2004.

9. Erell E., Pearlmutter D., Williamson T. Urban Microclimate: Designing the Spaces Between Buildings. - London ; Washington, DC, 2012- $452 \mathrm{P}$

10. Landsberg H. E. The Urban Climate. - N.Y., 1981.

11. Landsberg H. E. The Urban Climate // International Geophysics Series. - 1981 - Vol. 28 - P. 769-779.

12. Oke T. R. Boundary Layer Climates. - 2nd ed. - M., L., N.Y., 1987.

13. Oke T.R., Mills G., Christen A., Voogt J.A. Urban Climates. - C., 2017.

14. Santamouris M., Papanikolaou N., Koronakis I., Livada I. Asimakopoulos D. Thermal and air flow characteristics in a deep pedestrian canyon under hot weather conditions // Atmospheric Environment. - 1999. Vol. 33. - P. 4503-4521. 
О. Шевченко, канд. геогр. наук, доц.,

С. Снижко, д-р геогр. наук, проф.

Киевский национальный университет имени Тараса Шевченко, Киев, Украина

\section{ВЕТРОВОЙ РЕЖИМ БОЛЬШОГО ГОРОДА}

Рассмотрено особенности ветрового режима урбанизированной среды. Освещены главные факторы, определяющие формирование поля ветра большого города. Раскрыт механизм и описаны необходимые условия для образования сельского бриза. Описаны основные трансформации воздушного потока в городском каньоне, которые могут формироваться в зависимости от направления ветра, а также от характеристик и направления каньона. Приведены особенности обтекания воздушным потоком отдельных зданий и описаны зона смещения воздушного потока, зона ветровой тени и зона выравнивания потока, которые при этом формируются.

Ключевые слова: ветер, ветровой режим большого города, урбанизированная среда, ослабление воздушного потока в городе, сельский бриз, аэрация большого города, ветровая тень, трансформации ветра в городском каньоне.

O. Shevchenko, PhD Geography, Associate Professor,

S. Snizhko, Doctor of Geographical Sciences, Professor

Taras Shevchenko National University of Kyiv, Kyiv, Ukraine

\section{BIG CITY WIND REGIME}

Big city wind regime is an important factor which influences on air pollution level and bioclimate of the territory. It forms as a result of climatic conditions influence and the impact of various objects (height and density of construction, road network, green zones, water bodies etc.) within the city. The article is devoted to the study and analysis of big city wind regime, as well as generalizing of the basic knowledge about air flow transformation in urban areas for future using this information in scientific research and for the correction of aeration regime of different territories. Wind speed reduction is the main feature of urban areas wind regime. Usually wind velocity in the city is approximately $30 \%$ lower compared to it neighborhoods. Not only the mean wind speed is lower in urban areas, but also the vertical wind profile is characterized by some differences. Urban heat island existence leads to the formation of a mesoscale thermal circulation in the city - a rural breeze which is the most pronounced under conditions without wind or with weak wind speed. Transformation of air flow in an urban street canyon depends on the wind direction - when the wind is directed parallel to the canyon axis, wind within canyon has a higher velocity (according to the Venturi effect). In a street canyon which is oriented with its axis perpendicular to the wind direction, when air flows across the cross-section of a canyon, a vortex is formed and accordingly wind velocity is getting lower. Depending on the characteristics of the canyon (its height/width and length/width ratio) three distinct wind regimes may be identified in the canyon - isolated roughness flow regime, wake interference regime and skimming flow regime. Thus, the wind field has a very complex structure in the urban areas, because on air flow in city influence a lot of factors.

Key words: wind, big city wind regime, urban area, wind speed reduction in a city, rural breeze, big city aeration, wind shade, transformation of air flow in an urban street canyon.

\section{TERRITORIAL AND LOGISTICAL ORGANIZATION OF URBAN TOURISM IN CONTEXT OF ITS SUSTAINABLE DEVELOPMENT (UKRAINE'S CASE)}

The territorial and logistic aspects of the integrated strategy of sustainable development of urban tourism, based on two concepts-tourism decentralization and reverse logistics are outlined. The first concept is based on the geologistical organization of the tourist space of the city, which includes such components as: geologistical (geographical and logistical) identification of the resource base of urban tourism; geologistical planning of tourist flows and determination of their needs; geologistical design of tourist infrastructure; geologistical design of supply chains of tourist infrastructure. At the same time, the geographical identification of the resource base of urban tourism means geospatial localization of tourist objects in the city. They should be considered as a kind of "tourist magnets", which attract the flow of tourists to certain parts of the city. Accordingly, the territorial concentration of tourist objects causes a concentration of tourist flows, therefore these considerations should be taken into account when creating and placing new tourist objects in certain parts of the city, so that there will be no territorial oversaturation of them. Consequently, instead of the territorial concentration of tourist objects in the central parts of the city, their territorial dispersion, that is, dispersion across the city territory, should be proposed. Logistical identification of the resource base of urban tourism means the definition of the logistic potentials of individual tourist objects, that is, the maximum possible tourist flows, which will not affect the sustainable development of tourism and the state of tourist resources. Geologistical planning of tourist flows and their needs means forecasting the size and structure of tourist flows and their needs, which can be divided into needs of the first and second levels. Geologistical planning of tourist infrastructure is to develop a network of tourism infrastructure objects in order to meet the previously determined needs of tourists of the first and second levels. The geologistical design of supply chains to ensure the functioning of tourism infrastructure objects includes the development of territorial transport and logistic schemes for their supply, taking into account the characteristics of the road network of cities and the locations of the objects themselves.

The second concept involves an integrated approach to the recycling of the total amount of urban waste, including tourist one, taking into account their collection and removal from the city, as well as processing at special enterprises. The experience of Ukrainian cities of Lviv and Kyiv in this context is considered. At the same time Kyiv is more efficient in processing municipal waste, including tourist one, and Lviv faces the problem of the removal and recycling of urban waste, including tourist, over which the city now works.

Key words: urban tourism, complex strategy, sustainable development, territorial and logistic approaches, tourist decentralization, reverse logistics.

Relevance of the scientific question. Urban tourism nowadays is becoming more and more popular both in Ukraine and in the world. Urban turism has its own peculiarities connected with the high concentration of tourists on the limited territory of cities, especially their central and historical parts. In connection with this, there is a problem of tourist load increasing on the resource base of tourism in cities, which can lead to its deterioration and degradation. To solve this problem is possible by using integrated geologistical approach to the sustainable development of urban tourism.

Study of the issue in scientific literature. Attention to this problem in the scientific literature for the time being is insufficient [1], while in practical management of urban tourism development, this problem is already well-known and reflected in the development and adoption of relevant 